\title{
Africa's Natural Resource Wealth: A Paradox of Plenty and Poverty
}

\author{
Ukertor Gabriel Moti \\ (Professor of Public Sector Management and Governance) \\ Department of Public Administration, University of Abuja-Nigeria
}

\begin{abstract}
Africa is blessed with vast natural resources and rich environments. It is generously endowed with productive land and with valuable natural resources, which include renewable resources (such as water, forestry, and fisheries) and non-renewable resources (minerals, coal, gas, and oil). Natural resources dominate many national economies and are central to the livelihoods of the poor rural majority. These resources are the basis of income and subsistence for large segments of Africa's population and constitute a principal source of public revenue and national wealth. Under the right circumstances, a natural resource boom can be an important catalyst for growth, development, and the transition from cottage industry to factory production. Indeed, with the right approach natural resources can be used to make the transformation from a low-value economy that relies on exports of primary commodities to one with a substantial labour-intensive manufacturing base. Ideally the development of these resources can be a blessing for the entire continent. But historically, those resources have often proved to be a curse than a blessing especially to the majority of the citizens in these African countries. It is commonly agreed that one of the avenues for getting many of the poorest African countries out of the low-income trap is to provide them with a big demand push that will generate enough demand complementarities to expand the size of markets and recover the fixed costs of industrialisation. Natural resource wealth could be used to pursue this goal. Unfortunately, in many African countries natural resource booms have only to a limited extent set off a dynamic growth process. This is largely due to failure to implement the right growth promotion policies and to ensure that strong institutions are in place, suggesting that it is very difficult to make the big push towards diversification and development of manufacturing in the resource-rich parts of Africa. The danger is that much of Africa is not industrialised and is stagnating in a staple trap, dependent on exports of a few mineral resources. In particular, oil resources and other point resource-dependency could, with the wrong policies, lead to this scenario. The failure of natural resource wealth to lead to the expected economic growth and development has been attributed to several factors, including the so-called "Dutch Disease", rent seeking by elites, poor governance and weak institutions. The paper explores these causes of the resource curse and suggests ways to get out of the syndrome.
\end{abstract}

Key Words: Dutch Disease, Natural Resource, Poverty, Resource curse, Wealth,

\section{INTRODUCTION}

The term 'resource curse' refers to the idea that the possession of natural resources (particularly in the form of oil or minerals) does not necessarily lead to economic success, and that resource wealth can even have a structural negative impact on long-term economic development. While it seems strange to suggest that a country could be economically (as well as socially and politically) hindered by its possession of a valuable - and often essential economic input, scholars who believe in the resource curse suggest that, more often than not, resource-rich or resource-dependent countries are worse off compared to countries with few natural endowments. 
Since the Scramble for Africa began in the nineteenth century, Africa's natural resources have attracted a lot of attention. It may come as somewhat of a surprise that the African continent was not the main supplier of any of the central raw materials of great importance in the nineteenth century global economy. For instance, of the natural resources coal, iron, oil, cotton, rubber and copper, only rubber was a primarily colonial product, and four-fifths of the world's supply was derived in British Malay and the Dutch East Indies. More recently, many African countries are increasingly rich in oil, diamonds and minerals. Yet, African countries have and continue to experience low levels of economic growth and development.

By contrast, in the second half of the twentieth century many East Asian economies have experienced very rapid economic growth and achieved Western living standards despite having no exportable resources. In 1993 Richard Auty, an economic geographer, coined the phrase 'natural resource curse' to describe this counter-intuitive phenomenon. Two years later, the economists Jeffrey Sachs and Andrew Warner initiated the big statistical literature on the subject. They found that dependence on natural resources was connected to low levels of economic growth. The relationship between economic growth (measured by the average annual growth of per capita Gross Domestic Product) and resource dependence (measured by the share of natural resources in total exports), is negative: this means that, at least for the period 1970 to 2008, the economies of countries whose wealth consisted mostly of natural resources grew at a slower rate than those with a lower share of resource wealth. Many scholars have argued that this relationship holds, on average, over different sample periods and for different measures of resource wealth. Sachs and Warner (1999), for example, claimed their findings are not easily explained by other factors or by alternative ways of measuring resource abundance or dependence. More recently, Frederick Van der Ploeg has pointed out the variety of experiences of resource rich countries, though noting that the resource curse is primarily a phenomenon of the last 40-50 years. He points to the benefits of natural resources for countries with "good institutions", free trade and high levels of investment in extractive technology (Van der Ploeg, 2007).

Many African countries are blessed with oil and mineral wealth that has the potential to transform their economies. Ideally the development of these resources can be a blessing for the entire continent. But historically, those resources have often proved to be a curse than a blessing especially to the majority of the citizens in these African countries. Part of the cause of this curse is attributed to the leadership crisis facing many countries on the African continent.

Leadership implies critical management of critical resource endowments in a country. Governance and leadership crises in Africa are reinforced by the inability of leaders to identify, sieve and apply relevant development policy options. There is the get - rich - quick mania in Africa, especially among the political leaders. The inordinate ambition for wealth accumulation is an offshoot of corrupt practices which are aspects of underdevelopment. An African also appears to be happy stealing from one side of his pocket and transfers the 'loot' to the other side of his pocket and congratulate himself for a job well done (Iheriohanma \& Oguoma, 2010). Resource - rich countries in Africa are plagued by political and commercial corruption, social inequality and the instability that results from systems that fail to meet the basic rights of its people. A continent that is rich in natural resources like oil, gas, diamonds and other extractive resources, is made poor by the human errors that are fed by greed (Coleman, 2011).

Are sub-Saharan Africa's abundant mineral and fuel resources undermining prospects for development in the region? An influential body of research asserts that natural resources curse the countries that possess them with a host of undesirable outcomes - from economic stagnation, to authoritarian rule, to violent conflict. Africa is no stranger to these maladies. 
With international commodity prices booming, its dependence on resource exports is unlikely to diminish anytime soon. Is Africa suffering from a resource curse? How can this be mitigated?

Africa has 23 Resource-rich countries and about 26 Resource-scarce countries, some landlocked, and some coastal.

Table 1 Resource-Rich \& Resource -scarce Countries

\begin{tabular}{|l|l|}
\hline Resource-Rich Countries & Resource Scarce Countries \\
\hline Oil Exporting Countries & Benin \\
\hline Algeria & Burkina Faso \\
\hline Angola & Burundi \\
\hline Cameroun & Cape Verde \\
\hline Chad & Comoros \\
\hline Congo & Djibouti \\
\hline Cote d'Ivoire & Egypt \\
\hline Equatorial Guinea & Eritrea \\
\hline Gabon & Ethiopia \\
\hline Libya & Ghana \\
\hline Nigeria & Guinea Bissau \\
\hline Sudan & Kenya \\
\hline South Sudan & Lesotho \\
\hline & Liberia \\
\hline Mineral Exporting Countries & Madagascar \\
\hline Botswana & Malawi \\
\hline Central African Republic & Morocco \\
\hline Ghana & Niger \\
\hline Guinea & Rwanda \\
\hline Mauritania & Sao Tome \& Principe \\
\hline Mozambique & Senegal \\
\hline Namibia & Seychelles \\
\hline Sierra Leone & Swaziland \\
\hline South Africa & Togo \\
\hline Tanzania & Tunisia \\
\hline Zambia & Uganda \\
\hline & Zimbabwe \\
\hline Source: Adapted rom African Development Report & \\
\hline
\end{tabular}

Source: Adapted from African Development Report, 2017.

Table 2 Landlocked and Coastal Countries

\begin{tabular}{|l|l|l|}
\hline Land Locked Countries & Coastal Countries & Coastal Countries \\
\hline Resource - Rich & Resource-Rich & Resource -Scarce \\
\hline Botswana & Algeria & Benin \\
\hline Central African Republic & Angola & Cape Verde \\
\hline Chad & Cameroun & Comoros \\
\hline & Congo & Djibouti \\
\hline Resource -Scarce & Congo Democratic Republic & Egypt \\
\hline Burkina Faso & Cote D'ivoire & Eritrea \\
\hline Burundi & Equatorial Guinea & Ghana \\
\hline Ethiopia & Gabon & Guinea Bissau \\
\hline Lesotho & Guinea & Liberia \\
\hline Malawi & Libya & Madagascar \\
\hline Mali & Mauritania & Morocco \\
\hline Niger & Mozambique & Sao Tome \& Principe \\
\hline Rwanda & Namibia & Senegal \\
\hline Swaziland & Nigeria & Seychelles \\
\hline Uganda & Sierra Leone & Somalia \\
\hline Zambia & Sudan & Togo \\
\hline & Tanzania & Tunisia \\
\hline
\end{tabular}

Source: Adapted from African Development Report, 2017 


\section{WHAT IS THE RESOURCE CURSE?}

The resource curse refers to a situation whereby a country has an export-driven natural resources sector that generates large revenues for government but leads paradoxically to economic stagnation and political instability. It is commonly used to describe the negative development outcomes associated with non-renewable extractive resources (petroleum and other minerals). Essentially, the resource curse refers to the inverse association between development and natural resource abundance. It has often been asserted that petroleum, in particular, brings trouble-waste, corruption, consumption, debt overhang, deterioration, falling apart of public services, wars, and other forms of conflicts, among others. Thus, natural resource abundant countries tend to grow slower than expected-considering their resource wealth - and, in many cases, actually grow slower than resource-scarce countries (ADB, 2007).

The resource curse (also known as the paradox of plenty) refers to the failure of many resource-rich countries to benefit fully from their natural resource wealth, and for governments in these countries to respond effectively to public welfare needs. While one might expect to see better development outcomes after countries discover natural resources, resource-rich countries tend to have higher rates of conflict and authoritarianism, and lower rates of economic stability and economic growth, compared to their non-resource-rich neighbours. The curse of natural resources (the observation that countries rich in natural resources tend to perform badly) has been shown empirically and analysed in a number of studies. These studies, which include Auty (1990), Sachs and Warner $(1995,1999)$, and Gylfason et al, (1999), among others, have emerged late in the 20th century, as evidence accumulated on the poor growth experience of resource-rich countries in the post-world-war II period. On an intellectual level, this issue first emerged as an important international issue during the inter-war period in Latin America, after many Latin American economies suffered from the global slumping of commodity prices. However, during this time and in the immediate post-war period, the scepticism about natural resource-led development was rooted in forecasts of declining global demand and prices. What the studies based on the post-war experience have argued is that the curse of natural resources is a demonstrable empirical fact, even after controlling for trends in commodity prices. Since so many poorer countries still have abundant natural resources, it is important to better understand the roots of failure in natural resource-led development.

\section{THE LITERATURE}

The theoretical literature on the resource curse contains many mechanisms that may explain why 'more leads to less'-in the sense that the general equilibrium effect of more natural resources may actually be lower income. The first wave of theory models to explain this was within what might be termed Dutch disease theory. Van Wijnbergen (1984) developed the first model showing how oil may reduce aggregate income through a learning-by-doing mechanism. When a country discovers oil, its population wants to spend part of the value of this as consumption of non-traded goods. Demand for these increases, pulling resources out of traded sectors, and decreasing production here. The decreased traded sector in turns means less learning by doing, and lower productivity growth than would otherwise be the case. This effect may be sufficiently strong to outweigh the initial increase in income that the oil discovery generated. Other models within the Dutch disease tradition include Krugman (1987), Matsuyama (1992), Sachs and Warner (1995), Gylfason et al. (1999), Torvik (2001), and Matsen and Torvik (2005).

The second wave of models explaining the resource curse consisted of rent-seeking models. A standard result in the rent-seeking literature is that when a new income possibility arises, this may lead to increased rent seeking that reduces the net increase in income for society. 
However, the extent of rent dissipation falls short of one and so the net increase in income is still positive. The more agents that undertake rent seeking, the less total income increases. Note that these theories cannot explain what is normally understood as the resource cursethat more natural resources decrease total income. The literature on rent seeking and the resource curse thus models different reasons why the extent of rent dissipation may exceed one-in which case more natural resources may push total income down. The most famous paper within the rent-seeking tradition of the resource curse is Tornell and Lane (1999). They show how, in an economy with many groups, an increase in the marginal productivity may actually reduce growth: when the marginal productivity increases this means more income available for redistribution. Each group in the economy demands higher transfers, and the sum of these demands may make the tax rate go up sufficiently that the net marginal productivity of capital, and thus growth, is reduced. In Torvik (2002) we see that entrepreneurs can use their talent running modern firms or otherwise to undertake rent seeking in the hope of capturing some of the resource income of the economy. With more natural resources fewer entrepreneurs will run firms and more engage in rent seeking. In turn, this means that production in modern firms fall, reducing income and demand further, making it even less profitable to run modern firms. Through rent seeking more natural resources generate a negative multiplier effect, and the net result is lower income. Other resource-curse models within the rent-seeking tradition include, among others, Baland and Francois (2000), Hodler (2006), Mehlum et al. (2006), and Wick and Bulte (2006).

\section{CAUSES AND EFFECTS OF THE RESOURCE CURSE}

Political scientists and economists argue that oil, mineral and gas wealth is distinct from other types of wealth because of its large upfront costs, long production timeline, site-specific nature, scale (sometimes referred to as large rents), price and production volatility, non-renewable nature, and the secrecy of the industry. Below are some of the leading observations and theories about how these special characteristics of natural resource revenues create additional challenges for countries:

Countries with non-renewable resource wealth face both an opportunity and a challenge. When used well, these resources can create greater prosperity for current and future generations; used poorly, or squandered, they can cause economic instability, social conflict, and lasting environmental damage. Why a 'Resource Curse'? The discovery of natural resources leads to concentration of wealth in hands of a few - powerful officials in governments and those directly involved in drilling, mining and resource exploration (like International Oil Companies). The discovery of these resources hence becomes a blessing only to these few while it excludes the majority from any benefits. It's upon this ground that it has been commonly referred to as the "resource curse".

The resource curse, has crippled many African nations since their independence. Cases like Angola, Sudan, the DRC, Gabon, Equatorial Guinea, Sierra Leone, Liberia, Nigeria and several others, have endured the hardships brought on by the presence of highly sought after raw materials, notably oil and precious gemstones (Mbabazi, 2009). Among the major causes of Africa's resource curse include but not limited to; lack of strong legal and political institutions, presence of multiple power groups (actors), dictatorial and repressive governments among others. All these causes stem from poor leadership and weak governance that exists in many African states today.

Weak Legal and Political institutions: Strong legal and political institutions play an important role in the development of any country. Unfortunately most resource-rich countries of Africa are characterised by weak governance, outdated laws and weak institutional capacity. Outdated laws create a conflict of interest within the agency responsible for managing the 
sector (Global Witness et al, 2011). Because of the nature of the political system where power is concentrated in ruling families or powerful individuals and cabals, the legal system and other institutions especially economic have been either weak or marginalized (Abbas, 2009).

Presence of Multiple Power Groups: In most African countries, there are several actors involved in the oil and mineral sector. These groups may include governments, Transnational Corporations, NGOs, and Donor Agencies among others. All actors exert a certain degree of power and multiple interests. As one of the sovereign authorities, the government is, undoubtedly, the primary actor in the country's oil and mineral sector. For example, from licensing companies to developing national policies, the governments of Nigeria and Uganda are the most influential and crucial actors. With this power, however, comes a level of great responsibility. If power is misused, the likely benefits from the resources can become a curse to the entire nation as the wealth from the oil and mineral sector concentrates in the hands of a few powerful officials.

Dictatorial and Repressive Regimes: Most African countries have experienced dictatorial regimes that cling to power, so that they monopolise collection of resource wealth. Many studies have demonstrated a causal relationship between natural resources and authoritarianism, finding that natural resources negatively impact democracy. Authoritarianism arises due to one-party dominance combined with weak rule of law. This incites the opposition to use non-constitutional means to compete for political power. In response, the incumbent pre-empts this move by repressing or banning the opposition party. However, when the rule of law is strong and political power is less concentrated, and distribution of resource rents is properly monitored by an independent agency, the incumbent's advantage is largely mitigated (UNDP, 2010). Generally speaking, all the factors behind the 'resource curse' in Africa are attributed to weak governance.

Democracy: Natural resource wealth, particularly oil wealth, has made it more likely for governments to become or remain authoritarian over the past 30 years. The explanation for this lies in taxation. In general, political scientists find that governments are more responsive to their citizens and are more likely to transition to democracy when government spending is reliant on citizen taxation. When countries collect large revenues from natural resources, they are less dependent on levying taxes on citizens, and thus citizens feel less invested in the national budget. Politicians and government officials are also less directly tied to citizen requests or demands. Further, when resource revenues are secret, citizens do not have a clear sense of whether the resource revenues are being spent well or not. Those who outline this theory suggest that the tendency toward authoritarianism can be mitigated by increasing transparency of revenues and strengthening the links between government and citizens through citizen participation in budgeting or direct distribution of wealth (e.g., cash transfers) (UNDP, 2010).

Natural Resource Bounties and Armed Conflict: Natural resources can, and often do, provoke and sustain internal conflicts as different groups fight for control of the resources or use natural resources to finance their fighting. Since 1990, oil-producing countries have been twice as likely to have a civil war compared with non-oil-producing countries. Political scientists point to examples of the Democratic Republic of the Congo, the Niger Delta (Nigeria), Libya and Angola to illustrate this tendency. Petro-aggression, the tendency of oil rich states to instigate or be targets of international conflict, has been observed in some cases, such as with Iraq's invasion of Iran and Kuwait, but researchers debate whether the data supports the conclusion that resource-rich countries do this at a greater rate than non-resource-rich countries (Mabikke, 2012). 
There is a growing body of empirical evidence that rents on natural resources and primary commodities, especially oil and other point-source natural resources, increase chances of civil conflicts and wars in Sub-Saharan Africa through weakening of the state or financing of rebels, sometimes even by multinational corporations. It is important to investigate whether civil strife and wars are the result of grievance, a sense of injustice about how a social group is treated (e.g., systematic economic discrimination), or greed possibly induced by massive rents of point-source resources as in Angola, Congo and Sierra Leone (Murshed, 2002; Olsson and Fors, 2004). The extent of primary commodity exports is the largest single influence on the risk of conflict and the effect is nonlinear (Collier and Hoeffler, 2004). For instance, a country with no natural resources has a probability of civil conflict of merely 0.5 percent, but a country with a share of natural resources in GDP of a quarter has a probability of 23 percent. Unfortunately, this suggests that many conflicts are driven by greed rather than grievance.

In this context, it is important to note that insisting on reforming towards democracies is not necessarily very helpful in countries with abundant natural resources. In fact, resource-rich democracies tend to have lower growth unless these democracies have sound and effective checks and balances (Collier and Hoeffler, 2006). In many resource-rich countries the government seems unable to provide basic security to its citizens, since the wealth of resources elicits violence, theft and looting often financed by rebels and competing war lords ( Skaperdas, 2002; Mehlum, et al, 2002). The effect of natural resources on the incidence and duration of civil wars features also strongly in the political science literature (Ross, 2004; Fearon and Laitin, 2003). In fractionalised countries with many rival groups, fighting about natural resources may harm the quality of the legal system and thus undermine property rights. The resulting destruction of output.

Effectively, natural resource wealth implies that opportunistic, rebel leaders crowd out ideological leaders and that government end up being corrupt and concerned with looting for themselves and their cronies rather than investing in public goods for the people outweighs the increase in output due to the resource boom, but not in homogenous countries. There will thus be an erosion of property rights and a natural resource curse if the number of rival fractions is large and natural resource revenues are substantial. Fractionalisation and fighting about natural resource bounties can thus lead to over dissipation of natural resource rents. Erosion of property rights when there are lots of natural resources can easily lead to a natural resource curse, especially if there are many rival fractions (Hodler, 2006). The idea is that each group manages to appropriate more natural resources if they fight more and the quality of the legal system is poor, but fighting also undermines effective property rights. If a country is homogenous, there is no fighting and thus no undermining of property rights. In that case, a natural resource bonanza always benefits consumption of its citizens.

Inefficient spending and borrowing: The amount that governments collect in resource revenues can change drastically from year to year because of changes in commodities prices and production. Several studies have shown that it is very difficult to effectively spend fluctuating and unpredictable revenues. Governments often get trapped in boom-bust cycles where they spend on legacy projects, such as airports and monuments, when revenues are rising and then must make painful cuts when revenues decline. Resource-rich governments have a tendency to over-spend on government salaries, inefficient fuel subsidies and large monuments and to underspend on health, education and other social services. In addition, governments often over-borrow because they have improved credit-worthiness when revenues are high. This type of behaviour led to debt crises when revenues declined in Mexico, Nigeria and Venezuela in the 1980s. The private sector can be similarly impacted, as it can 
over-invest in boom times and then experience widespread bankruptcy during busts (Torvik, 2002).

Proponents of the resource curse hypothesis identify several channels through which natural resources may harm development. In the economic sphere, lucrative natural resources attract attention and assets from other sectors with greater long-term growth potential. In the political sphere, the effects of natural resources depend on whether the state is able to capture resource wealth. Where the state does capture resource wealth, proceeds from resource extraction enable governments to use a mix of patronage and repression to evade meaningful accountability to the general public. Where it does not, proceeds from resource extraction enable the rebel groups that control them finance violent insurgencies.

African countries such as Angola, Nigeria, Sierra Leone, Sudan, and Republic of Congo are rich in oil, diamonds and other minerals, and yet residents have a low income and low quality of life. On the other hand, East Asian countries like Japan, Korea, Taiwan, Singapore and Hong Kong have almost reached the standard of the West, although they are actually peninsulas without the export of natural resources and any significant amount of natural resources. Some countries did gain positive benefits, which can be attributed to the wealth of natural resources.

If one considers the definition of economic growth and the impact of the export of natural resources from countries that are rich in them, the given situation presents incomprehensible mystery which shows that in this case the wealth in natural resources and export of natural resources, not necessarily affect the increase in GDP and the increase in economic growth in the long term. For example, the countries that are one of the largest oil producers in the world, such as Algeria, Angola, Iran, Saudi Arabia, Venezuela and even Trinidad and Tobago, have experienced a significant decline in per capita income in recent decades, and as one of the most negative examples is Nigeria, where $70 \%$ of the population lives on less than one dollar a day, which is disappointing if we take into account the fact that Nigeria earned over 340 billion dollars in revenue from the production and export of oil since 1970 (Schubert, 2006).

Many African countries are rich in natural resources. This has not always been a blessing. The huge revenues from commodity exports have been very volatile. Furthermore, these revenues are often temporary and thus sound fiscal policies are required to ensure that sufficient investment takes place in productive and human capital for when resources run out. This is a difficult task, since the volatility of commodity export revenues invites excessive public spending without proper scrutiny. The huge volatility of resource prices also harms both domestic and foreign direct investment and depresses economic growth by a large amount, especially if domestic financial institutions are poorly developed. Many resource-rich African countries also suffer from real appreciation of their exchange rates induced by the huge resource export revenues and aid flows. This really hampers prospects for non-resource exports in those countries. The sheer volume of resource revenues diverts attention away from the task of diversifying exports away from commodities to labour-intensive manufacturing exports.

The rise of China and India make it extra difficult for Africa to carve a niche in labour-intensive manufacturing exports to the OECD economies. Something must be done, since Africa cannot afford to wait until wages in China and India have risen sufficiently for Africa to get a chance. Without proper checks and balances the huge resource revenues also encourage rent seeking and corruption on a massive scale and tend to undermine the quality of institutions. Transparency of the allocation of mineral right, the revenues generated, and how the revenues are spent, are thus essential. Outside credible international organisations preferably organised 
by reform-minded African institutions could play a useful role in extending the Extractive Industries Transparency Initiative into a Charter for Transparency of Resource Revenues and Payments. Unfortunately, many rich countries have negative genuine saving. They are thus depleting their natural resource wealth faster than they are building up other assets. The key challenge is therefore how to transform the often temporary resource revenues into a productive capital. Clearly, much can be done to improve the transport infrastructure, especially for the landlocked countries of Africa. Also, much can be done to invest in human capital and the skill necessary to set up a viable and competitive manufacturing base.

\section{INSTITUTIONS AND THE NATURAL RESOURCE CURSE}

Here we offer arguments why booms in natural resource revenues often lead to rapacious rent seeking, corruption and armed conflict and thereby undermine growth prospects, albeit that these adverse effects can be avoided to an extent if the quality of institutions is good and the political system is blessed with effective checks and balances. Since institutions are not necessarily cast in stone and can be improved in the course of a couple of decades (IMF, 2005), there is a challenge for resource-rich African countries to improve their institutions and soften the blows of the resource curse.

Natural Resource Bonanzas Invite Rapacious Rent Seeking: The political economy of massive natural resource rents can be horrendous especially when combined with badly defined property rights, imperfect markets and poorly functioning legal systems. Such situations provide ideal opportunities for rent seeking behaviour of enterprises, politicians and their friends, thereby diverting resources away from more productive economic activities (Auty, 2001, 2004). Self-reinforcing effects arise if rent seekers compete and prey on productive entrepreneurs and can explain wide cross-country differences in rent seeking (Murphy, et al, 1993; Acemoglu, 1995). The idea is that each country has a limited pool of talented people, who can either engage in productive entrepreneurship or in wasteful rent seeking. A larger number of rent seekers in resource-rich economies lower returns to not only rent seeking, but also to entrepreneurship with possibly large marginal effects on production. Since more entrepreneurs are likely to switch to rent seeking in times of a natural resource boom, there is a possibility of multiple (good and bad) equilibrium outcomes. More rent seekers induce negative external effects that depress profits for remaining entrepreneurs, which stimulate even more people to shift from productive entrepreneurship to wasteful rent seeking. It is also possible that increased entrepreneurship crowds out rent seeking. In particular, private business can invent and supply new substitutes for restricted imports and thus destroy the rents of quota licenses (Baland and Francois, 2000).

The so-called voracity effect also causes a drag on economic growth in fractionalised societies as can be seen after the oil windfalls in Nigeria, Venezuela and Mexico (Tornell and Lane, 1999). This effect implies that dysfunctional institutions and poor definition of property rights lead to a classical commons problem whereby there is too much grabbing and rapacious rent seeking of natural resource revenues. It supposes, in contrast, a fixed number of rent seekers. Capital can be allocated either to a formal sector where rents may be appropriated and an informal sector with lower returns and no appropriation or rent seeking. Competing groups in society can thus invest in private assets with relatively low returns or grab as much as they can from the stock of common natural resources. In a natural resource boom returns to capital investment in the formal sector rise, so that rent seekers can appropriate proportionately more without destroying the incentive to invest in the formal sector. This is the case if there is the possibility of sectoral reallocation or, alternatively, if the elasticity of intertemporal substitution is sufficiently high so that groups do not refrain from excessively increasing appropriation of natural resource revenues. 
Natural Resource Wealth Induces Corruption: There is much anecdotal evidence that suggests that corruption is rampant in resource-rich societies and that it is harmful for economic incentives. In fact, cross-country empirical evidence also establishes that increased corruption hampers economic growth (Mauro, 1995; Bardhan, 1997; Leite and Weidmann, 1999). Mineral wealth may prevent the redistribution of political power towards the middle classes and thus hamper the adoption of growth-promoting policies (Bourguignon and Verdier, 2000). The main thrust of these explanations is that natural resource wealth has an adverse effect on institutions, since excessive natural resource revenues allow governments to pacify dissent, avoid accountability and resist modernisation (Isham, et al., 2003). For example, waste, corruption and the granting of import licenses and other privileges to cronies rather than Dutch Disease effects operating through the real exchange rate seem to be why oil riches have had such disastrous effects on long-run performance of the Nigerian economy (Sala-iMartin and Subramanian, 2003). Resource wealth makes it easier for dictators to buy off political challengers as President Mobuto has been able to do in Congo with its wealth on copper, diamonds, zinc, gold, silver and oil (Acemoglu, Robinson and Verdier, 2004). Natural resource riches allow politicians to bribe voters by offering them well paid, but unproductive jobs and inefficient subsidies and tax handouts (Robinson, Torvik, and Verdier, 2006).

If institutions are strong and encourage productive entrepreneurship, profits of entrepreneurs increase. This means that eventually less people engage in rent seeking and more in productive activities. The rent of the resource bonanza is more than dissipated. Examples of resource rich countries with strong institutions are Australia, Canada, the US, New Zealand, Iceland and Norway, but also Botswana (Acemoglu, Johnson and Robinson, 2003a). However, if institutions are weak, the legal system dysfunctions and transparency is low, rent seeking has a higher return and unfair take-overs, shady dealings, corruption, crime, etc. pay off. A resource bonanza thus elicits more rent seekers and reduces the number of productive entrepreneurs. In the long run profits fall and as a result the economy is worse off. Weak institutions may explain the poor performance of oil rich countries such as Angola, Nigeria and Sudan, diamond rich Sierra Leone, Liberia and Congo, and drug states like Columbia or Afghanistan. In those countries institutions are often destroyed by civil wars over the control of natural resources. Dependency on oil and other natural resources hinders democracy and the quality of governance (Ross, 1999). Summing up, among the group of resource-rich African economies there are a few countries with strong institutions that enjoy higher growth but unfortunately many others with weak institutions that suffer from low growth resulting from corruption induced by substantial natural resource revenues.

Sub-Sahara Africa, with lower income than South Asia, faces the greater challenge and need. While the two regions account for approximately $45 \%$ of the population of the developing countries, Sb-Sahara Africa account for a much higher proportion of poverty in its various manifestations, generally well over $70 \%$. $75 \%$ of the income poverty $63 \%$ of the chronically hungry $72 \%$ of the children out of school $75 \%$ of the illiterate adults $86 \%$ of the people living with HIV/AIDS $94 \%+$ of the malaria deaths $84 \%$ of the Under- 5 Mortality $86 \%$ of the Maternal Mortality $87 \%$ of those practicing open defecation $73 \%$ of the stunted children (Global Profile of Extreme Poverty. Background paper for the High-Level Panel of Eminent Persons on the Post-2015 Development Agenda, 2012). Some of these include resource-rich (dependent) countries as shown in tables 3 and 4 below. 
Country

Guinea

Democratic Republic of Congo

Zambia

Niger

Botswana

Namibia

Sierra Leone
Table 3 Sub-Sahara Africa's Most Mineral Dependent States

Mining product as percentage of GDP

84.7

80

74.8

70.6

70

55.4

50

Source: Weber-Fahr, 2018

Table 4 Sub-Sahara Africa's Most Oil Dependent States

$\begin{array}{lc}\text { Country } & \text { Oil Exports as percentage of GDP } \\ \text { Equatorial Guinea } & 86 \\ \text { Gabon } & 73 \\ \text { Congo } & 67 \\ \text { Angola } & 45 \\ \text { Nigeria } & 40 \\ \text { Cameroun } & 4.9\end{array}$

Source: U.S Energy Information Administration, (2010).

\section{CROSS-COUNTRY EVIDENCE FOR THE NATURAL RESOURCE CURSE}

Although there are resource rich countries that benefit from their natural wealth, the economies of many other resource-rich countries are in a terrible state. Natural resource wealth may harm economic performance and make citizens worse off. There are well-known examples of countries whose abundance of natural resources have gone together with bad macroeconomic performance and growing inequality among its citizens, but also of other countries which have benefited from their natural resource wealth. A dramatic example is Nigeria (Sala-i-Martin and Subramanian, 2003). Nigeria has since 1965 been a major oil exporter and oil revenues per capita have increased tenfold in the next 35 years, but income per capita has stagnated since independence in 1960 making Nigeria among the 15 poorest countries in the world. During this period the poverty headcount ratios have almost tripled while the rich have grabbed a much larger part of income. Huge oil exports have not benefited the average Nigerian. Despite rapid accumulation of physical capital, Nigeria has suffered a declining TFP and capacity utilisation of manufacturing hovers around a third. Two thirds of capacity often owned by the government goes to waste. Successive military dictatorships and politicians have plundered oil wealth and many suspect transfers of large amounts of undisclosed wealth. Oil wealth has fundamentally altered politics and governance in Nigeria.

Below (table 5) are countries that are claimed to have escaped resource curse and countries that are claimed not to have escaped resource curse. Among those that have escaped resource curse in Africa is Botswana (see Appendix B for details). Those that have not escaped resource curse are Algeria, Congo, Sierra Leone, Zambia and notably Nigeria (see Appendix A for details on Nigeria). 
Table 5 Resource -free and Resource -trapped Countries

\begin{tabular}{|l|c|l|l|}
\hline $\begin{array}{l}\text { Countries claimed to } \\
\text { have escaped the } \\
\text { resource curse }\end{array}$ & $*$ & $\begin{array}{l}\text { Countries claimed not to have } \\
\text { escaped the resource curse }\end{array}$ & $*$ \\
\hline Australia & 18.0 & Algeria & 6.11 \\
\hline Botswana & 33.0 & Congo & -11.9 \\
\hline Canada & 15.7 & Mexico & 10.8 \\
\hline Chile & 7.4 & Nigeria & -22.0 \\
\hline Ireland & 22.0 & Saudi Arabia & -21.5 \\
\hline Malaysia & 19.9 & Sierra Leone & -1.8 \\
\hline New Zealand & 18.4 & Trinidad \& Tobago & -3.9 \\
\hline Norway & 17.0 & Venezuela & -1.8 \\
\hline Oman & -26.6 & Zambia & -5.8 \\
\hline Thailand & 20.0 & & \\
\hline USA & 15.1 & & \\
\hline
\end{tabular}

Source: Matson and Tonvik (2017).

*Note: Resource-adjusted savings as percentage of Gross National Income

Other oil exporters such as Iran, Venezuela, Libya, Iraq and Kuwait and Qatar experienced negative growth during the last few decades. The OPEC as a whole saw a decline in GNP per capita. The gold price boom in the 1970's together with increased barriers to technological adoption helps to explain the de-industrialisation and disappointing growth experience of South Africa. In contrast, Botswana has managed to beat the resource curse. Forty percent of Botswana's GDP stems from diamonds. It has the second highest public expenditure on education as a fraction of GDP, enjoys the world's highest growth rate since 1965. Its GDP per capita is ten times that of Nigeria. The Botswana experience is noteworthy, since it started its post-colonial experience with minimal investment and substantial inequality.

Curse is Less Severe in Open Economies with Good Institutions: The pioneering study on the empirical cross-country evidence shows that resource rich countries grow on average about one percentage point less during 1970-89 even after controlling for initial income per capita, investments during the period, openness and rule of law (Sachs and Warner, 1995). Resource-rich countries with bad institutions typically are poor and remain poor. Many of them are in Africa. Other cross-country evidence strongly suggests that natural resources - oil and minerals in particular - exert a negative and nonlinear impact on growth via their deleterious impact on institutional quality rather than via a worsening of competitiveness (Sala-i-Martin and Subramanian, 2003). The adverse effect of resource abundance on institutional quality and economic growth is especially strong for easily appropriable 'pointsource' natural resources with concentrated production and revenues and thus massive rents, i.e., oil, diamonds, minerals and plantation crops rather than agriculture (e.g., rice, wheat and animals) whose rents are more dispersed throughout the economy, and with easy appropriation of rents through state institutions. What matters is thus the appropriability of resources, which is how easy it is to realise large economic gains within a relatively short period and having control over the resources. It is important to distinguish two distinct hypotheses (Boschini, et al, 2003).

\section{VIABILITY OF AFRICA'S NATURAL RESOURCES}

We first established that many resource-rich countries in Africa are squandering their natural resource wealth. They are saving and investing less in productive assets at home or abroad than their mineral and energy wealth is being eroded. As a result, so-called genuine saving rates are negative for many countries in Africa. One theoretical possibility for this is anticipation of better times (e.g., anticipation of improvements in exploration technology or commodity price hikes), but this seems unlikely. Extrapolating historical commodity price 
trends cannot explain the magnitude of the negative genuine saving rates. We therefore suggest that much of the negative genuine saving rates must be explained by rapacious rent seeking. Resource-rich countries of Africa therefore need credible and transparent rules for sustainable consumption and investment to ensure that exhaustible natural resources are gradually transformed into productive assets at home or abroad.

Much of Resource-Rich Africa Has Negative Genuine Saving: Many economies endowed with abundant natural resources varying from oil, gas and diamond to copper and tin have poor growth performance even after controlling for the quality of institutions, openness, investment rates and initial levels of income per capita. These countries also save less than the rents from extracting and selling natural resources. If they were to save more, they might grow at a faster rate. They squander their natural resources at the expense of future generations without investing in other forms of intangible or productive wealth. Highly resource dependent Nigeria and Angola have genuine saving rates of minus 30 percent, thereby impoverishing future generations on a massive scale. High natural resource dependence is defined as at least a 5 percent share of resource rents in GDP. The World Bank suggests that resource-rich countries with negative genuine saving such as Nigeria or Venezuela would experience increases in productive capital by a factor of five or four if the Hartwick rule would have been followed (Arezki and van der Ploeg, 2007). This is also true for oil- and gas-rich Trinidad and Tobago and copper-rich Zambia. All the countries in the top right quadrant (except Trinidad and Tobago) have experienced declines in per capita income from 1970 to 2000.

\section{MANAGEMENT OF NATURAL RESOURCE REVENUES}

The objective of maximising benefits to current and future generations of citizens can be broken down into four stages, relating to the stages from extraction, through revenue flows to expenditure. Here we therefore first discuss how efficient contracts could be written with the exploration companies and then discuss the appropriate choice of fiscal regime. We proceed with emphasising how important transparency of natural resource payments and spending of the resulting revenues is and offer some suggestions for more effective public sector financial management. We then discuss the timing of natural resource expenditures and especially how this can benefit future generations as much as possible. Finally, we discuss issues of whether natural resource revenues should be used for consumption and/or investment.

Contracting and the Fiscal Regime. There is a complex interaction between licensing, contracting and taxation regimes for natural resources. They need to secure the dual objectives of efficiency and revenue transfer to the host country. Sound principles for the design of efficient contracts and the auction and allocation of mineral and energy rights are needed. Efficiency imposes a number of requirements. Of course, exploration companies should have incentives to participate. They should also be encouraged to extract efficient quantities and to invest in both production and exploration. This in turn requires that contracts are timeconsistent, so that governments do not have an incentive to renege thereby creating uncertainty and expropriation threat.

Efficiency applies not only to the stream of output, but also to the allocation of production and price risks between parties to the contract. This allocation of risks depends on the ability of exploration companies and governments to bear risk and to trade risk on the international capital markets. The contract may also specify environmental conditions as well as the transfer of knowledge and other assets, tangible and intangible. In resource countries that are ruined by armed conflict an effort should be made to get exploitation companies involved at the peace negotiations table. Since the exploration companies have an interest to avoid conflict, they may have an incentive to help secure re-employment of ex-combatants. 
Revenue Transparency and Public Financial Management: Crucial is not to squander the natural resource wealth in a short period of time, but to make it last for future generations as well. It is therefore crucial that public and corporate accountability and transparency of all activities to do with the exploitation of natural resources is of the highest standards. The accounts related to the production and exports of resources should be available to journalists, financial analysts and the general public. Resource rich governments should also publish what they borrow, since some are tempted to loot the public purse by saddling future generations with excessive debt using natural resource reserves as collateral. Unfortunately, many countries that are worst affected by the natural resource curse do not publish what they earn from exports and do not publish where the revenues go to. Voluntary compliance is likely to fail, but exploitation corporations still have to deal with unrepresentative governments.

Corporate ethics and codes of governance in resource rich countries with poor institutions are thus crucial. Exploitation companies should publish their payments to all governments and may use their influence individually and industry-wide to support mandatory mechanisms for disclosure. Governments on whose territory exploitation companies are registered may require mandatory reporting of revenues to all governments, encourage corporate social responsibility and punish illegal exploitation of natural resources and collusion in the perpetuation of resource-driven conflict. Mandatory compliance may help. It also ensures a level playing field among exploitation corporations and avoids unfair competition from corporations unconstrained by human right or anticorruption concerns.

\section{BREAK THE CURSE - IMPROVE GOVERNANCE AND LEADERSHIP}

Governance is the way in which society is managed and how the competing priorities and interests of different groups are reconciled. Governance is concerned with the processes by which citizens participate in decision-making, how government is accountable to its citizens and how society obliges its members to observe its rules and laws (FAO, 2007). Governance can be briefly described as the way in which the underlying values of a nation (usually articulated in some way in its Constitution) are "institutionalised". This has formal aspects such as separated powers, checks and balances, means of transferring power, transparency, and accountability. However, for these values to be actualised, they must guide the actions of public officials throughout the system. They must be imbedded in culture. Failure in governance has adverse impacts for the society. Good governance is closely related to good leadership. Leadership is a critical component of good public governance. In this regard "leadership" is the flesh on the bones of the Constitution. It is at the heart of good governance.

The most important role of public sector leaders has been to solve the problems and challenges faced in a specific environment. When we say we want more leadership in the public sector, what we are really looking for is people who will promote institutional adaptations in the public interest. Leadership in this sense is not value neutral. It is a positive espousal of the need to promote certain fundamental values that can be called public spiritedness. Therefore, leadership is an important and crucial variable that leads to enhanced management capacity, as well as organisational performance.

Good Governance, why it's very important? Good governance means that government is well managed, inclusive, and results in desirable outcomes. Good governance is accountable. Accountability is a fundamental requirement of good governance. Good governance is transparent. People should be able to follow and understand the decision-making process. Good governance follows the rule of law. This means that decisions are consistent with relevant legislation or common law. Good governance is responsive. Good governance is equitable and inclusive. Good governance is effective and efficient. Good governance is 
participatory. These are the principles lacking in most African governance because of poor leadership quality.

The principles of good governance can be made operational through equity, efficiency, effectiveness, transparency and accountability, regulatory quality and rule of law, control of corruption as well as sustainability, subsidiarity, civic engagement, security and political stability. Unfortunately, many African countries that are rich in natural resource are suffering from weak governance. One of the major characteristic of weak governance is corruption. This is exacerbated by lack of transparency and accountability among governments and Transnational Corporations (TNC) that are directly involved in the oil and mineral sector. Much of the corruption associated in oil and mineral sector happens at the beginning of the process - right when contracts are awarded to oil companies, or the oil services companies that increasingly construct and run oil infrastructure in Africa (Taylor, 2008).

In most resource-rich countries, the agreements signed between governments and TNC involved in oil and mineral development are hidden and treated with top secrecy from public and sometimes the parliament. The failure of governments and oil firms from disclosing what should be public information such as cost of oil exploration, environmental impact assessment as well as incident reports partly explains why violence in these countries is inevitable especially when the local populations in resource -rich areas feel excluded by governments from benefiting from the resources.

In order to suppress opposition, government forces and armed groups have vied for control of resources, with the proceeds from their sale funding more weapons, which prolongs the violence. Examples include bloody conflicts in DR Congo, Liberia, Ivory Coast and Sierra Leone which have all been partly funded by the sale of blood diamonds (Tutton, 2010). It's widely believed that in African resource- rich countries where good governance is taking a firm root, resource wealth can lead to economic growth and poverty reduction. Countries like Botswana with its diamond wealth and mineral- rich Ghana have proved that Africa's wealth of resources can be a blessings and not a curse. Countries like Uganda that have recently found huge oil deposits should learn from these success stories to avert past mistakes.

Governance indicators such as government effectiveness, voice and accountability, political instability and violence, the rule of law, regulatory quality, and control of corruption are markedly weaker in oil rich African countries (see Table 6). Perhaps, surprisingly, mineralrich countries actually perform much better and at the same level as resource-scarce countries, implying that this problem is by far most common in relation to oil exploration and revenue, at least at the present phase of the current resource boom. Governance remains the overarching and most critical challenge for natural resource exploitation and management. Although African governments bear prime responsibility for managing natural-resource wealth in a transparent, fair, and accountable way, they are only one part of an intricate web of interests and relationships, which include multinational extractive company's foreign governments, and regional actors 




Source: Kauffman, D; Kraay, A and Mashuzi, M. (2017); Transparency.org.

Note: Voice and Accountability (Reflects perceptions of the extent to which a country's citizens are able to participate in selecting their government, as well as freedom of expression, freedom of association, and a free media). Political Stability (Political Stability and Absence of Violence/Terrorism measures perceptions of the likelihood of political instability and/or politically-motivated violence, including terrorism). Government Effectiveness (Reflects perceptions of the quality of public services, the quality of the civil service and the degree of its independence from political pressures, the quality of policy formulation and implementation, and the credibility of the government's commitment to such policies). Regulatory Quality (Reflects perceptions of the ability of the government to formulate and implement sound policies and regulations that permit and promote private sector development). Rule of Law (Reflects perceptions of the extent to which agents have confidence in and abide by the rules of society, and in particular the quality of contract enforcement, property rights, the police, and the courts, as well as the likelihood of crime and violence). Control of Corruption (Reflects perceptions of the extent to which public power is exercised for private gain, including both petty and grand forms of corruption, as well as "capture" of the state by elites and private interests). 


\section{CONCLUSION AND RECOMMENDATIONS}

Africa is a continent that is blessed with a wealth of resources including copper, diamonds, gold and oil. This wealth could be a source of prosperity that could redeem the continent from debt burdens, bad aid and foster development. Despite the enormous potential that can arise from wealth of its resources, poverty remains firmly entrenched in many African countries. Resource - rich countries have experienced several conflicts resulting into forced immigration of people, death and destruction of property and the environment mainly due to bad governance. With exception of a few countries like Botswana and Ghana which have benefited from good leadership, functioning democracy and competent legal and political institutions, they have proved that natural resources can be a blessing rather than a curse on the African continent.

Monies for Africa's natural resources must be directed into the right pockets and not padding Transnational Corporate greed. Companies must publish what they pay foreign governments. In order for governments to be transparent, they should disclose agreements and all laws regarding minerals to the public. Greater access to information such as the cost of exploration and environmental impact statements must be accessible to all stakeholders. African governments need to establish transparent, inclusive and independent institutions/ agencies that should strictly revise contract allocation process, develop comprehensive reforms and carry out adequate planning. A set of new laws should be developed and obsolete ones revised in order to protect the institutions responsible for managing the oil and mineral sector.

The first key message is that countries with a large share of primary exports in GNP have bad growth records and high inequality, especially if the quality of institutions and the rule of law are bad and restrictions to international trade are imposed. Resource-rich countries typically suffer from an overvalued real exchange rate and a shift of labour and capital from the traded to the non-traded sectors. Since the traded sectors are most likely to enjoy learning by doing and other knowledge externalities, the growth engine will falter or not pick up at all. Countries with abundant point-source natural resources are also prone to civil conflict and war.

The second key message is that resource-rich countries are vulnerable to the well-known volatility of commodity prices which has a strong negative effect on growth performance. More important, is that countries with well-developed financial markets and relatively open to international trade seem to benefit from their natural resources provided their economies are not too volatile. The quintessential feature of the natural resource curse is the volatility of commodity prices. Countries that are rich in natural resources, have lots of trade restrictions and bad functioning financial markets and are landlocked, experience the greatest volatility and thus have to put up with depressing growth prospects. Unfortunately, this applies to much of resource-rich Africa.

The third key message is that to avoid or attenuate the natural resource curse, appropriate policies are called for. One of these may be a temporary subsidy or tax relief for the nonresource export sectors that are hurt by a worsening of competitiveness resulting from the natural resource bonanza and consequently forego learning by doing and other spill-over effects. But such subsidies are merited even in the absence of natural resources. Given the rapid growth of China and India, it is very tough for many African economies to diversify and develop a labour-intensive manufacturing base. This problem is aggravated by the natural resource curse. There are therefore good arguments for exempting especially the resource-rich economies of Africa from tariffs on exports of labour-intensive manufacturing to the developed world. This may just be the temporary boost those countries need to get out of their poverty 
traps. China and India are important players in the new scramble for Africa's resources, but they also provide a unique opportunity for Africa to develop and diversify its export base.

The fourth key message is that countries with large natural resource reserves are tough to reform, since the political elite and their cronies resist undermining of their resource rents. The staple trap view suggests two possible roads for successful economic reform. The experience of Indonesia and Mexico suggests that, if oil reserves per capita are low, rapid economic reforms will be more likely to occur as they nurture wealth creation. However, if natural resource reserves sustain rents for a long period in heavily distorted economies, more gradual dual-track economic reforms may prove viable as long as the winners of reform can compensate the losers. This can be achieved by creating a dynamic market sector in early reform geographic enclaves that offer domestic and foreign investors immediate access to post-reform conditions of infrastructure, institutions and incentives. Rapid expansion of the enclaves absorbs surplus labour from the less dynamic, distorted sectors of the economy, and thus builds a pro-reform political constituency. Such gradual dual-track reform may be relevant for resource-rich of Algeria, Angola, and Nigeria.

The fifth key message is that sound natural resource management implies that countries should invest their natural resource rents into reproducible assets such as physical and human capital. The objective is to transform exhaustible natural resource wealth into reproducible assets with a visible rate of return such as public infrastructure, education and foreign investment.

However, a recent World Bank study suggests that many resource-rich economies in Africa squander their natural resource wealth and have negative genuine saving rates. They then grow less. The challenge is thus to make sure that the resource-rich countries invest their often temporary stream of natural resource revenues in productive assets and thus spread the benefits over a longer time and to future generations.

The sixth key message is that practical suggestions for efficient allocation of mining contracts and better management of natural resources are needed. Botswana, Canada, Australia and Norway suggest that it is possible to escape the resource curse. The first-best strategy is to improve the quality of institutions and the legal system and to insist on accountability and transparency of resource revenues, but vested interests may oppose that. It may also help to put natural resource revenues in a fund to ensure that the interest of future generations is safeguarded, but in countries with poor institutions such a fund will probably be raided. An interesting alternative is to change the constitution in order to guarantee that natural resource revenues are handed to the public. The government has to subsequently tax its citizens to finance its spending programmes and the burden of proof for spending resource revenues is with the government.

The final, and most critical key message is the role of leadership and good governance in pulling and tying together the above key messages. The marginal overall improvement in good governance in Africa in the past decade must be sustained. Africa, especially, resource-rich countries must go for quality leadership that will build institutions, foster democracy and good governance in order to effectively manage natural resources for development and mitigate the resource curse. 


\section{References}

Abbas, Ali J. (2009) Business and Management Environment in Saudi Arabia: Challenges and Opportunities for Multinational Corporations.

Acemoglu, D., and Robinson, J. A. (2006), 'Economic Backwardness in Political Perspective', American Political Science Review, 100, 115-31.

Acemoglu, D. (1995). Reward structures and the allocation of talent, European Economic Review, 39, 17-33.

Acemoglu, D., S. Johnson and J.A. Robinson (2003a). An African success: Botswana, in D. Rodrik (ed.), In Search of Prosperity. Analytic Narratives in Economic Growth, Princeton University Press, Princeton.

Acemoglu, D., J.A. Robinson and T. Verdier (2004). Kleptocracy and divide-and-rule: a theory of personal rule, Journal of the European Economic Association, 2, 162-192.

Acemoglu, D. and J.A. Robinson (2005). Economic backwardness in political perspective, American Political Science Review.

African Development Bank (2007) 'Chapter 4: Africa's Natural Resources: The Paradox of Plenty' in African Development Report 2007.

Arezki, R. and F. van der Ploeg (2007). Can the natural resource curse be turned into a blessing? Role of trade policies and institutions, Working Paper 07/55, International Monetary Fund, Washington, D.C.

Aslaksen, S. and R. Torvik (2005). A theory of civil conflict and democracy in rentier states, mimeo. Norwegian University of Science and Technology, Trondheim.

Aslaksen, S. (2006), 'Corruption and Natural Resources: Evidence from Panel Data', Department of Economics, Norwegian University of Science and Technology, mimeo.

Auty, R.M. (2001) (ed.). Resource Abundance and Economic Development, Oxford University Press, Oxford.

Auty, R.M. (2004). Economic and political reform of distorted oil-exporting economies, presented at The Earth Institute, Columbia University.

Baland, J. M. and P. Francois (2000). Rent-seeking and resource booms, Journal of Development Economics, 61, 527-542.

Bardhan, P. (1997). Corruption and development: a review of the issues, Journal of Economic Literature 35, 13201346.

Boschini, A.D., J. Pettersson and J. Roine (2003). Resource curse or not: a question of appropriability, SSE/EFI

Working Paper Series in Economics and Finance No. 534, Stockholm University, Stockholm.

Boschini, A. D., Pettersson, J., and Roine, J. (2007), 'Resource Curse or Not: A Question of Appropriability', Scandinavian Journal of Economics, 109, 593-617.

Bourguignon, F. and T. Verdier (2000). Oligarchy, democracy, inequality and growth, Journal of Development Economics, 62, 285-313.

Caselli, F. (2006). Power struggles and the natural resource curse, mimeo. London School of Economics, London.

Caselli, F. and W.J. Coleman II (2006). On the theory of ethnic conflict, Discussion Paper No. 5622, CEPR, London.

Coleman K., (2011) Africa's Natural Resources: Blessing or Curse?

Collier, P. (2007). The Bottom Billion, Oxford University Press, Oxford.

Collier, P. and A. Hoeffler (2004). Greed and grievance in civil wars, Oxford Economic Papers, 56, 663-695.

Collier, P. and A. Hoeffler (2006). Testing the Neocon Agenda: Democracy in resource-rich societies, mimeo, University of Oxford.

Damania, R., and Bulte, E. (2003), 'Resources for Sale: Corruption, Democracy and the Natural Resource Curse', University of Adelaide, mimeo.

David, P. A., and Wright, G. (1997), 'Increasing Returns and the Genesis of American Resource Abundance', Industrial and Corporate Change, 6, 203-45.

FAO (2007) Good Governance in Land Tenure and Administration: Food and Agriculture Organization of the United Nations (FAO, Land Tenure Series 9).

Fearon, J.D. and D.D. Laitin (2003). Ethnicity, insurgency, and civil war, American Political Science Review, 97, 7590. 
Global Witness, CENTAL, LDI, LMI, SDI (2011) Curse or Cure: How oil can boost or break Liberia's Post War Recovery, September 2011.

Gylfason, T., Herbertson, T. T., and Zoega, G. (1999), 'A Mixed Blessing: Natural Resources and Economic Growth', Macroeconomic Dynamics, 3, 204-25.

Gylfason, T., Zoega, G. (2002a). Inequality and Economic Growth: Do Natural Resources Matter? CESifo Working Paper Series No. 712.

Gylfason, T., Zoega, G. (2002b). Natural Resources and Economic Growth: The Role of Investment. Central Bank of Chile Working Papers, 1-52.

Hodler, R. (2006). The curse of natural resources in fractionalized countries, European Economic Review, 50, 1367-1386.

Humphreys, M., J. Sachs and J.E. Stiglitz, (2007) 'Escaping the resource curse' Revenue Watch.

Iheriohanma E.B.J, \& Oguoma O., (2010), Governance, Leadership Crisis and Underdevelopment in Africa: An Explorative Discourse. European Journal of Social Sciences Volume 12, Number 3.

IMF (2005). Building Institutions, Chapter 3, 125-160 in World Economic Outlook, Building Institutions, September 2005, International Monetary Fund, Washington, D.C.

IMF (2007). Regional and Economic Outlook: Sub-Saharan Africa, World Economic and Financial Surveys, International Monetary Fund, Washington, D.C.

Isham, J., L. Pritchett, M. Woolcock and G. Busby (2003). The varieties of the resource experience: How natural resource export structures affect the political economy of economic growth, World Bank, Washington D.C.

Johnson, S. Robinson, J. A., and Verdier, T. (2004), 'Kleptocracy and Divide-and-rule: A Theory of Personal Rule', Journal of the European Economic Association, 2, 162-92.

Krugman, P. (1987) .The Narrow Moving Band, The Dutch Disease and the Competitive Consequences of Mrs Thatcher: Notes on Trade in the Presence of Dynamic Scale Economies. Journal of Development Economics 27: 4155 .

Leite, C. and M. Weidmann (1999). Does Mother Nature corrupt? Natural resources, corruption and economic growth, WP/99/85, IMF, Washington D.C.

Mabikke, S. B. (2012), Africa's Wealth of Resources, Blessing or Curse?, African Good Governance Network. www.hss.de/download/120120 makikke.pdf (accessed, 12, April, 2017).

Mbabazi, P.K (2009) The Emerging Oil Industry in Uganda; A Blessing or a Curse: African Research and Resource Forum.

Matsen,E.,andTorvik,R.(2005),'OptimalDutchDisease',JournalofDevelopmentEconomics,78,494-515.

Matsuyama, K. (1992), 'Agricultural Productivity, Comparative Advantage, and Economic Growth', Journal of Economic Theory, 58, 317-334.

Mauro, P. (1995). Corruption and growth, Quarterly Journal of Economics, 90, 681-712.

McPherson, C. (2004), Managing Petroleum Revenues in Developing Countries, presented at the Workshop Escaping the Resource Curse, Columbia University Workshop, 26/2.

Mehlum, H., and Moene, K. (2002), 'Battle Fields and Market Places', Journal of Defence Peace Economics, 6, 85-96.

Mehlum, H., K. Moene and R. Torvik (2002). Plunder \& Protection Inc., Journal of Peace Research, 39, 447-459.

Mehlum, H., K. Moene and R. Torvik (2006). Institutions and the resource curse, Economic Journal, 116, 1-20.

Murphy, K., A. Schleifer and R. Vishny (1993). Why is rent-seeking so costly to growth?, American Economic Review, Papers and Proceeding, 409-414.

Murshed, S.M. (2002). Civil war, conflict and underdevelopment, Journal of Peace Research, 39, 387-393.

U.S Energy Information Administration, Washington DC. (2010).

Olsson, O. and H.C. Fors (2004). Congo: The prize of predation, Journal of Peace Research, 41, 3, 321-336.

Ollson, 0. (2007). Conflict diamonds, Journal of Development Economics, 82, 267-286.

Papyrakis, E., Gerlagh, R. (2003). The resource curse hypothesis and its transmission channels. Journal of Comparative Economics 1-13. 12. 
Ploeg, F. van der (2006). Challenges and opportunities for resource rich economies, Discussion Paper No. 5688, CEPR, London.

Ploeg, F. van der (2007). Why do many resource-rich countries have negative genuine saving rates? Anticipation of better times or rapacious rent seeking, mimeo.

Robinson, J.A., R. Torvik and T. Verdier (2006). Political foundations of the resource curse, Journal of Development Economics, 79, 2, 447-468.

Ross, M.L. (1999). The political economy of the resource curse, World Politics, 51, 297-322.

Ross, M.L. (2001). Timber Booms and the Institutional Breakdown in Southeast Asia, Cambridge University Press, Cambridge.

Ross, M.L. (2004). What do we know about natural resources and civil war?, Journal of Peace Economics, 41, 337356.

Ross, M. (2012). The Oil Curse How Petroleum Wealth Shapes the Development of Nations. Princeton: Princeton University Press.

Sachs, J.D. (1999). Resource endowments and the real exchange rate: a comparison of Latin America and East Asia, in T. Ito and A. Krueger (eds.), Changes in Exchange Rates in Rapidly Developing Countries: Theory, Practice and Policy Issues, Chicago University Press, Chicago.

Sachs, J.D. and A.M. Warner (1995 and revised 1997). Natural resource abundance and economic growth, in G. Meier and J. Rauch (eds.), Leading Issues in Economic Development, Oxford University Press, Oxford.

Sachs, J.D. and A.M. Warner (1999). The big push, natural resource booms and growth, Journal of Development Economics, 59, 43-76.

Sachs,J.D.,andWarner,A.M.(1995),'NaturalResourceAbundanceandEconomicGrowth',NBERWorking Paper No. 5398.

Sachs, J., Warner, A. (1999a). 'The big push, natural resource booms and growth', Journal of Development Economics, 59(1), 43-76. 20.

Sala-i-Martin, X. and A. Subramanian (2003). Addressing the natural resource curse: An illustration from Nigeria, NBER Working Paper 9804, Cambridge, Mass.

Samuelson, P. A., \& Nordhaus, W. D. (2000). Ekonomija. Zagreb: MATE.

Schubert, S. R. (2006). Revisiting The Oil Curse: Are Oil Rich Nations Really Doomed To Autocracy And Inequality? Oil and Gas Business.

Skaperdas, S. (2002). War lord competition, Journal of Peace Research, 39, 435-446.

Taylor, S (2008) Testimony for Hearing “Resource Curse or Blessing: Africa's Extractive Industries in a Time of Record Oil and Mineral Prices" Senate Foreign Relations Committee, Subcommittee on Africa, Global Witness.

Tornell, A. and P.R. Lane (1999). The voracity effect, American Economic Review, 89 (1), 22-46.

Torvik, R. (2001). Learning by doing and the Dutch Disease, European Economic Review, 45, 285-306.

Torvik, R. (2002). Natural resources, rent seeking and welfare, Journal of Development Economics, 67, 455-470.

UNDP (2010) Human Development Research Paper 2010/04: Curse or Blessing, Natural Resources and Human Development.

van der Ploeg, F. (2007), 'Challenges and Opportunities for Resource Rich Economies', OXCARRE, Oxford University, mimeo.

van Wijnbergen, S. (1984), 'The 'Dutch Disease’: A Disease After All?', The Economic Journal, 94, 41-55.

Vincent, J.R., Th. Panayotou and J.M. Hartwick (1997). Resource depletion and sustainability in small open economies, Journal of Environmental Economics and Management, 33, 274-286.

Weber-Fahr, M. (2002).Treasure or Trouble? Mining in Developing Countries. Washington, DC: World Bank Group and International Finance Corporation.

Wick, K., and Bulte, E. (2006), 'Contesting Resources-Rent Seeking, Conflict and the Natural Resource Curse', Public Choice, 128, 457-76.

World Bank (2006). Where is the Wealth of Nations? Measuring Capital for the 21st Century, International Bank for Reconstruction and Development/World Bank, Washington, D.C. 


\section{ABOUT THE AUTHOR}

Ukertor Gabriel Moti (Ph.D) is a Professor of Public Administration in the Department of Public Administration, University of Abuja, Nigeria, specialising in Public Sector Management and Governance. A former Deputy Dean of the Faculty of Management Sciences, he has held several administrative positions in the University including membership of the University Senate representing the Faculty of Management Sciences. Prof. Moti is a Fellow of the Certified Public Administrators of England and Wales (FCPA), Fellow, Institute of Management Consultants (FIMC), Member, Committee for the International Conference on Management, Leadership and Governance (IMCLG), United Kingdom in addition to membership of several other professional bodies such as the African Association for Public Administration and Management (AAPAM). He has published over 40 articles in peer reviewed local and international academic journals. Professor Moti was among the 25 African scholars that participated in the China-Africa Research Exchange Programme (2016) where he served as Leader of the Africa-China Delegation. Moti is Co-chair with Dr.Steve Troupin on the AAPAM-IIAS Taskforce for Public Administration Research Capabilities in Africa under auspices of the International Institute of Administrative Sciences (IIAS, Belgium). Prof. Moti is a notable public policy analyst in Nigeria. His research interests include Public Sector Management and Governance, Public Policy Analysis, and Development Administration. He is a regular participant at various international conferences where he has presented papers. 